\title{
Altitudinal variations in soil physico-chemical properties at cold desert high altitude
}

\author{
G. Charan ${ }^{1}$, V. K. Bharti ${ }^{1 *}$, S.E. Jadhav², S. Kumar ${ }^{3}$, S. Acharya ${ }^{1}$, P. Kumar ${ }^{1}$, D. Gogoi ${ }^{1}$, R.B. Srivastava ${ }^{1}$ \\ ${ }^{1}$ Defence institute of High Altitude Research, DRDO, Io 56 APO, Leh-Ladakh (Jammu \& Kashmir), India. ${ }^{2}$ Defense Research \\ and Development Establishment, DRDO, Gwalior (Madhya Pradesh), India . ${ }^{3}$ Jaypee University of Information Technology, \\ Waknaghat, Solan (Himachal Pradesh), India Corresponding author: vijaykbharti@rediffmail.com
}

\begin{abstract}
Extreme nature of climate and topographical conditions may affect soil properties at cold desert high altitude. Hence, the present investigation was undertaken to know altitudinal variations in soil physico-chemical properties at cold desert high altitude region. For this, agriculture soils were collected from different altitude viz. site I (10000$11000 \mathrm{ft}$ ), site II (11000-12000 ft) and site III (>12000 ft amsl) at Leh-Ladakh (cold desert high altitude region), India. Interestingly, sand percentage in soil was significantly high at site III and decreased gradually with the altitude. In contrast to sand level, silt concentration was high at site I and decreased significantly $(p<0.05)$ with increasing altitude. There was no significant $(p<0.05)$ difference in bulk density (BD) and electrical conductivity (EC) among all study sites. However, the highest $\mathrm{pH}$, total dissolved solid (TDS), and $\mathrm{CaCO}_{3}$ value was recorded at site I while higher soil organic matter (SOM) was at site III. Pearson correlation coefficient analysis showed the negative correlation $(p<0.01, p<0.05)$ of clay, silt, and $\mathrm{pH}$, whereas positive correlation of sand and $\mathrm{SOM}(p<0.01)$ with altitude. Hence, our findings suggest the altitudinal variations in soil physico-chemical properties at cold desert high altitude.
\end{abstract}

Keywords : Altitudinal variation, cold desert, high altitude, physico-chemical properties, soil.

\section{Introduction}

Over the past decades, high altitude soils have attracted more attention in the debate on the potential impact of environmental changes on the global carbon cycle ( $\mathrm{Li}$ et al., 1998; Oechel et al., 2000). Recently, increased pressure on agriculture sector to produce more grains and fodder in cold desert high altitude region has raised the concern on soil health and their management practices (Sharma et al., 2006). Soils at cold desert high altitude are coarse textured, permeable, deserted, and having poor water and nutrient holding capacity has low nutrient availability for growing crops and perform differently in the different soil types (Jobbagy and Jackson, 2000; Dwivedi et al., 2005; Sharma et al., 2006). The soils of Leh-Ladakh i.e. cold desert high altitude region are poor in mineral nutrients, wind erosion occurs on a mammoth scale and paucity of water is a perennial blockage (Bowman et al., 2002; Ladakh Autonomous Hill Development Council, 2005; Sharma et al., 2006). Also, soil micro flora population is sparse due to poor soil structure, texture, very high 
sand and clay, low biological activity and freezing during long winter period in this region (Campbell and Claridge, 1987). The extremely high altitude of Himalaya probably provides a unique glacial climate on earth. In this area, sub zero temperature during maximum periods are responsible for different texture, mineralogy and very low soil development process indicating more advance stage of weathering. Altitude profoundly affects the soil's inherent fertility and runoff-erosion behavior (Mani, 1990; Bowman et al., 2002). Level of rainfall, snowfall, and temperature variation affects organic matter decomposition that affect accumulation of organic matter with elevation (Walker et al., 2000). These changes in microenvironment may affect physico-chemical characteristics of soil in this region hence there is need to study the physico-chemical characteristics of soil in this area. Many soil fertility characteristics (including organic matter content, $\mathrm{pH}$, cation exchange capacity, phosphate sorption, and phosphorus availability) show significant altitudinal variations (Jobbagy and Jackson, 2000). Since, crop production and soil managements differ with kind of soil and their physico-chemical behavior (Mani, 1990; Sharma et al., 2006). Therefore, in such fragile agro ecosystem soils need to be handled carefully for stabilized and sustainable crop production. Keeping the above circumstances and problems, the present study was designed to know the physico-chemical characteristics of agricultural soils along the altitudes gradients in cold desert high altitude region of Leh-Ladakh.

\section{Material and methods}

\subsection{Survey of Study site}

The study area lying Leh-Ladakh (10000 to $13060 \mathrm{ft}$. amsl, $33^{\circ} 59.362$ to $34^{\circ} 17.722 \mathrm{~N}$ latitude, and $077^{\circ} 12.023$ to $077^{\circ} 45.669 \mathrm{E}$ longitudes) which is situated in Eastern Ladakh Plateau a part of Tibetan Plateau (Figure 1). This comes under cold desert high altitude region and surrounded by the Indus and Zanskar Rivers under the rain shadow of the Himalayas. Annual precipitation is $<100 \mathrm{~mm}$ mostly in form of snow. The higher northern part of the Ladakh plateau remains under permanent snow cover. Temperature ranges from $-40^{\circ} \mathrm{C}$ to $+40^{\circ} \mathrm{C}$ and average relative humidity range is 24.70 and $39.03 \%$ (Table 1). The area dominantly represented by Ladakh series is classified as Typic Cryorthent (Mandal et al., 1999). High altitude causes reduced air density, vapor pressure, increased solar radiation, lower temperatures, increased wind velocity, high evaporation. Diversion of glacial fed rivers into stone built terraces and soil gathering through sedimentation enriches the soil with organic matter. Outflow of cold from the Himalayas produces a steeper temperature gradient due to their extremely high altitude. Interestingly, here growing time of crops varies considerably with altitude and decreases with the altitude.

\subsection{Soil sampling and processing:}

Total one hundred fourteen composite agriculture soil samples (Site I: 38, Site II: 38, and Site: 38 sample) were collected from different altitudes and locations of the sampling sites were recorded by GPS (global positioning system) coordinated in the center. Random soil sampling was preferred due to very small size of plots present in this region. Ten sampling points were selected at each sampling site, thereafter samples were collected from up to $15 \mathrm{~cm}$ soil depth (plough layer) and the required amount of soil sample was taken by quartering method. Root part and other plant residues were removed from the soil and then these soil samples were air dried at room temperature, sieved with $<2.0 \mathrm{~mm}$ test sieve.

For analysis of soil organic carbon (SOC) and calcium carbonate, soil samples were further sieved with 0.2 $\mathrm{mm}$ test sieve. The $\mathrm{pH}, \mathrm{EC}$, TDS, clay, sand, and silt were determined in $2.0 \mathrm{~mm}$ test sieve soil samples. For the bulk density (BD) determination, soil samples were collected at the same time and at same sampling sites using standard bulk density measuring container $\left(100 \mathrm{~cm}^{3}\right.$ in volume, $50.46 \mathrm{~mm}$ in diameter and $50 \mathrm{~mm}$ in height, Model NL 0303, Beijing New Landmark Soil Equipment Co. Ltd. Beijing China Mainland) and thereafter, samples were oven dried at $1050 \mathrm{C}$ for 24 hours. 


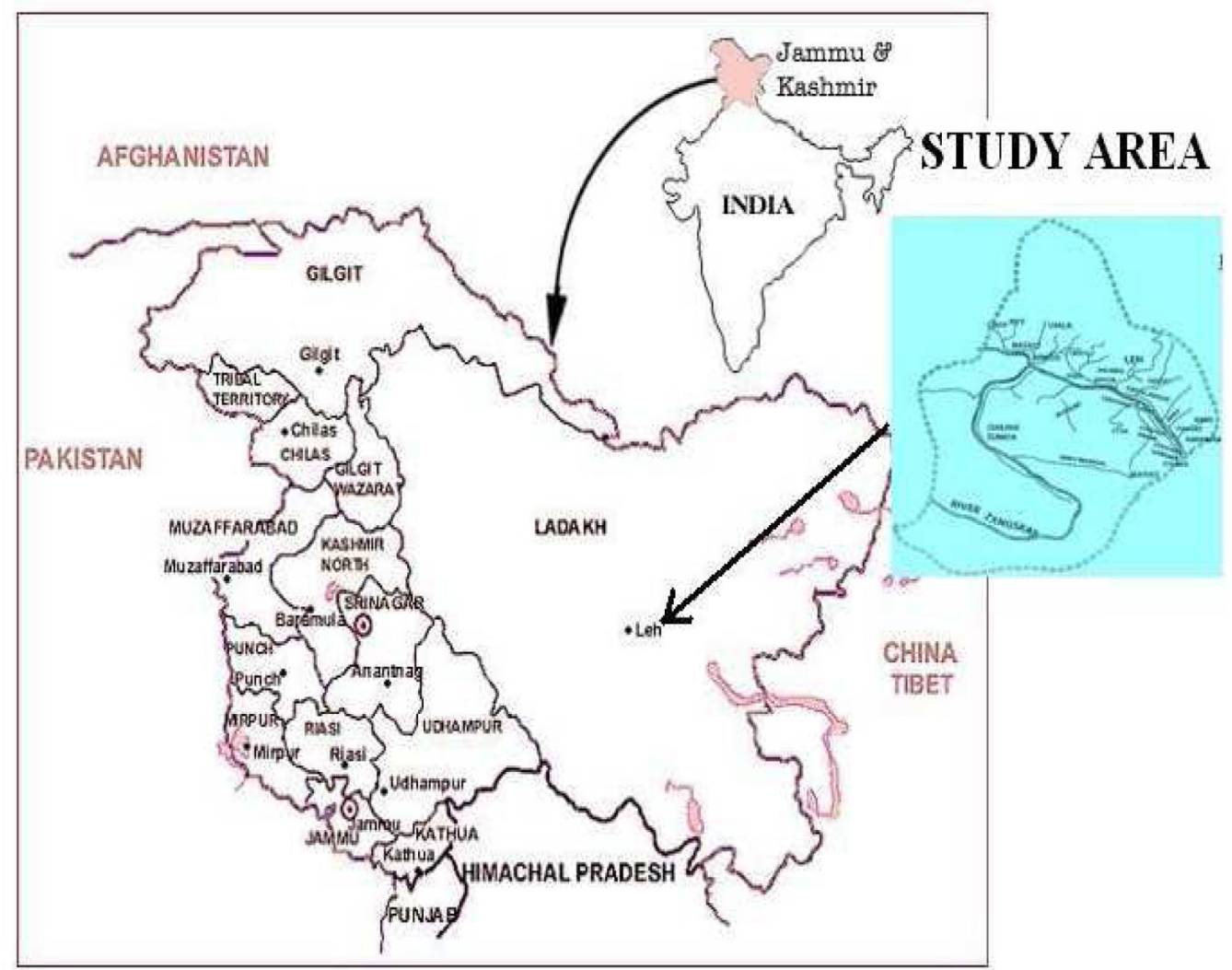

Figure 1. Map of study area

\subsection{Analysis of different parameters}

Chemicals and reagents used were GR grade, purchased from Merck, Germany. Soil organic carbon (SOC) was analyzed by wet digestion method (Walkley and Black, 1934). The organic matter content (OMC) was calculated by multiplying SOC content with Van Bemmelen factor (1.724). Total calcium carbonate content was estimated by Back titration method (Bashour and Sayegh, 2007) and PH, EC and TDS were measured as described by Tandon (1993) by preparing (1:2) soil and water solution for one hour were at rotary shaker. However, silt, sand and clay proportions were determined by bouyoucos hydrometer method.

\subsection{Statistical analysis}

Data generated through the study were analyzed for mean and standard error (SE). Significance level $(p<0.05)$ was generated among the different altitudinal study sites by one way ANOVA. Pearson correlation coefficient was done for the analysis of correlation in different physico-chemical properties of soil with altitudes using the computer program SPSS statistical software 17.0 versions for Windows. 
Table 1. Climatic data (for the year 2008-09) of studied area.

\begin{tabular}{lllllllll}
\hline \multirow{3}{*}{ Month } & \multicolumn{3}{c}{ Temperature ${ }^{0} \mathrm{C}$} & \multicolumn{3}{c}{ Relative Humidity \% } \\
\cline { 2 - 9 } & \multicolumn{2}{c}{2008} & \multicolumn{2}{c}{2009} & \multicolumn{2}{c}{2008} & 2009 \\
\cline { 2 - 8 } January & Min. & Max. & Min. & Max. & Min. & Max. & Min. & Max. \\
\cline { 2 - 8 } February & -15.21 & -3.95 & -13.92 & 0.40 & 35.39 & 48.29 & 27.42 & 39.97 \\
March & -16.21 & -2.81 & -10.89 & 3.98 & 29.10 & 47.93 & 23.50 & 36.75 \\
April & -1.66 & 13.42 & -2.07 & 13.78 & 27.30 & 45.57 & 21.40 & 30.50 \\
May & 2.61 & 18.18 & 1.98 & 17.82 & 27.58 & 52.23 & 21.77 & 28.94 \\
June & 10.96 & 26.22 & 5.24 & 21.15 & 22.63 & 33.70 & 26.70 & 28.17 \\
July & 12.34 & 27.31 & 10.97 & 24.62 & 22.90 & 39.16 & 21.13 & 37.00 \\
August & 9.82 & 25.40 & 14.16 & 26.55 & 25.39 & 51.87 & 20.06 & 29.13 \\
September & 3.77 & 17.80 & 6.67 & 21.08 & 27.30 & 45.93 & 21.53 & 35.57 \\
October & -2.41 & 15.03 & -0.57 & 13.85 & 26.26 & 41.55 & 21.33 & 38.97 \\
November & -8.62 & 11.03 & -10.03 & 4.07 & 21.03 & 33.40 & 29.07 & 47.40 \\
December & -11.64 & 5.95 & -17.78 & 2.45 & 22.55 & 37.16 & 24.65 & 32.46 \\
\hline
\end{tabular}

\section{Result}

\subsection{Clay, Sand and Silt proportions (\%)}

The present study revealed no variation in clay (\%) content, whereas sand content (\%) was significantly $(p<0.05)$ increased with the altitude (Table 2). However, silt (\%) content showed reversed trend, as they decreased significantly $(p<0.05)$ with the altitude (Table 2). Based on sand, silt, and clay content, textural class of agricultural soil comes under sandy loam at different altitude (Table 2).

The co-relation analysis revealed that clay (\%) and silt $(\%)$ are significantly $(p<0.05, p<0.01)$ negatively correlated with the altitude, whereas sand (\%) was positively correlated with the altitude (Table 3). Correlation analysis of properties among each other indicated the negative correlation between SOM and silt (\%), SOM and silt+clay (\%), however sand (\%) content was positively correlated with SOM (Table 4, Figures 2,3,4,5).

\subsection{BD, SOM and Calcium carbonate}

The values of $\mathrm{BD}\left(\mathrm{g} / \mathrm{cm}^{3}\right)$ have not shown any significant $(p<0.05)$ difference in all study sites, although the SOM content was reported significantly $(p<0.05)$ higher at the highest altitudinal site (site III) as compared to site I and II (Table 2). On the other hand the $\mathrm{CaCO}_{3}$ content (\%) was significantly $(p<0.05)$ maximum at site I and II (lower altitude site) as compared to site III (Table 2). Pearson correlation coefficient (r) analysis revealed that the SOM content $(\%)$ was significantly $(p<0.01)$ positive while $\mathrm{CaCO}_{3}$ $(\%)$ significantly $(p<0.05)$ negative correlated with altitude in the present study (Table 3). 
Table 2. Altitudinal variations in physico-chemical properties of cold desert agriculture soil.

\begin{tabular}{|c|c|c|c|}
\hline \multirow{3}{*}{ Parameters } & \multicolumn{3}{|c|}{ Study sites } \\
\hline & Site I (10000-11000 & Site II (11000- & Site $\mathrm{III}(>12000$ \\
\hline & $\mathrm{ft}$ amsl) & $12000 \mathrm{ft} \mathrm{amsl)}$ & $\mathrm{ft}$ amsl) \\
\hline Clay $(\%)$ & $12.53^{\mathrm{a}} \pm 0.32$ & $11.41^{\mathrm{a}} \pm 0.62$ & $10.96^{\mathrm{a}} \pm 0.76$ \\
\hline Sand (\%) & $52.40^{\mathrm{a}} \pm 1.20$ & $63.21^{\mathrm{b}} \pm 1.97$ & $69.99^{c} \pm 2.10$ \\
\hline Silt (\%) & $35.08^{\mathrm{c}} \pm 1.05$ & $25.38^{\mathrm{b}} \pm 1.77$ & $19.04^{\mathrm{a}} \pm 1.54$ \\
\hline $\mathrm{BD}\left(\mathrm{g} / \mathrm{cm}^{3}\right)$ & $1.38^{\mathrm{a}} \pm 0.01$ & $1.44^{\mathrm{a}} \pm 0.02$ & $1.43^{\mathrm{a}} \pm 0.03$ \\
\hline $\operatorname{SOM}(\%)$ & $1.42^{\mathrm{a}} \pm 0.09$ & $1.62^{\mathrm{a}} \pm 0.08$ & $2.45^{b} \pm 0.19$ \\
\hline $\mathrm{CaCO}_{3}(\%)$ & $6.26^{\mathrm{b}} \pm 0.07$ & $6.60^{b} \pm 1.50$ & $3.24^{\mathrm{a}} \pm 0.30$ \\
\hline $\mathrm{EC}(\mu \mathrm{s} / \mathrm{cm})$ & $331.07^{\mathrm{a}} \pm 52.58$ & $294.72^{\mathrm{a}} \pm 21.85$ & $273.88^{\mathrm{a}} \pm 18.22$ \\
\hline $\mathrm{pH}$ & $8.44^{b} \pm 0.04$ & $8.21^{\mathrm{a}} \pm 0.04$ & $8.25^{\mathrm{a}} \pm 0.07$ \\
\hline TDS (ppm) & $160.35^{b} \pm 12.12$ & $142.05^{\mathrm{a}} \pm 10.72$ & $131.82^{\mathrm{a}} \pm 8.89$ \\
\hline Textural class & Sandy loam & Sandy loam & Sandy loam \\
\hline
\end{tabular}

Values (mean \pm SE) bearing different superscript $(a, b, c)$ in a same row differ significantly $(p<0.05)$

Table 3. Correlation analysis of physico-chemical properties with altitude of cold desert agriculture soil

\begin{tabular}{|c|c|c|c|c|c|c|c|c|c|}
\hline & $\begin{array}{l}\text { Clay } \\
(\%)\end{array}$ & $\begin{array}{l}\text { Sand } \\
(\%)\end{array}$ & $\begin{array}{l}\text { Silt } \\
(\%)\end{array}$ & $\begin{array}{c}\text { BD } \\
\left(\mathrm{g} / \mathrm{cm}^{3}\right)\end{array}$ & $\begin{array}{c}\mathrm{CaCO}_{3} \\
(\%)\end{array}$ & $\begin{array}{c}\text { SOM } \\
(\%)\end{array}$ & $\mathrm{EC}(\mu \mathrm{s} / \mathrm{cm})$ & $\mathrm{pH}$ & $\begin{array}{c}\text { TDS } \\
(\mathrm{mg} / \mathrm{l})\end{array}$ \\
\hline $\begin{array}{c}\text { Pearson } \\
\text { Correlation } \\
\text { Coefficient }\end{array}$ & $\begin{array}{c}-0.179 \\
(*)\end{array}$ & $\begin{array}{c}0.408 \\
(* *)\end{array}$ & $\begin{array}{c}-0.413 \\
(* *)\end{array}$ & 0.114 & -0.158 & $\begin{array}{c}0.391 \\
(* *)\end{array}$ & -0.056 & $\begin{array}{c}-0.190 \\
\left(^{*}\right)\end{array}$ & -0.054 \\
\hline Sig. & 0.041 & 0.000 & 0.000 & 0.197 & 0.073 & 0.000 & 0.529 & 0.031 & 0.544 \\
\hline
\end{tabular}

** Correlation is significant at the 0.01 level (2-tailed).

* Correlation is significant at the 0.05 level (2-tailed). 


\section{3. $p H, E C(\mu s / c m)$ and TDS (ppm)}

The significantly $(p<0.05)$ maximum $\mathrm{pH}$ and TDS values were reported at site I (10000-11000 ft amsl) and lowest at site II (11000-12000 ft amsl) and site III (Table $2)$. However, the maximum values of $\mathrm{EC}(\mu \mathrm{s} / \mathrm{cm})$ was reported at site I and minimum value at site III respectively but there was no significant $(p<0.05)$ difference reported in all study sites (Table 2). Interestingly, $\mathrm{pH}$ was significantly $(p<0.05)$ negative correlated with altitude; however EC and TDS did not change along the altitude (Table 3).

Table 4. Correlation of soil organic carbon (SOM) content (\%) with sand, silt, clay, and silt + clay (\%) of cold desert agriculture soil.

\begin{tabular}{|l|c|c|c|c|}
\hline & Sand \% & Silt \% & Clay \% & Silt + Clay \% \\
\hline Pearson Correlation (r) & $0.451^{* *}$ & $-0.492^{* *}$ & -0.066 & $-0.451^{* *}$ \\
\hline Sig. (2 tailed) & .000 & .000 & .523 & 0.000 \\
\hline
\end{tabular}

** Correlation is significant at the 0.01 level (2-tailed).

* Correlation is significant at the 0.05 level (2-tailed).

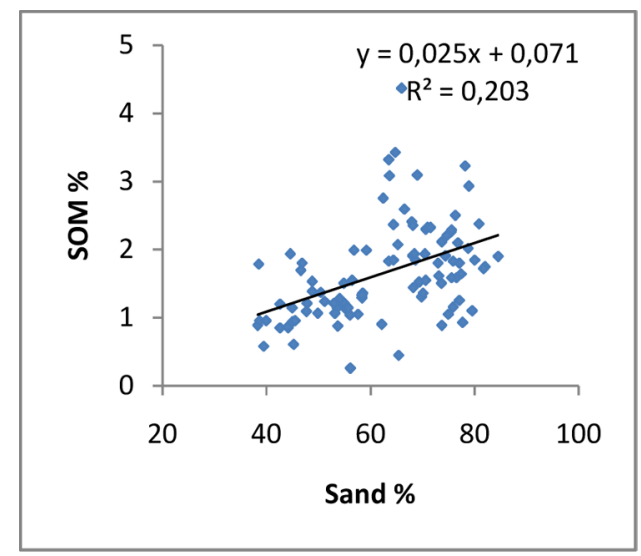

Figure 2. Correlation between SOM and Sand contents(\%)

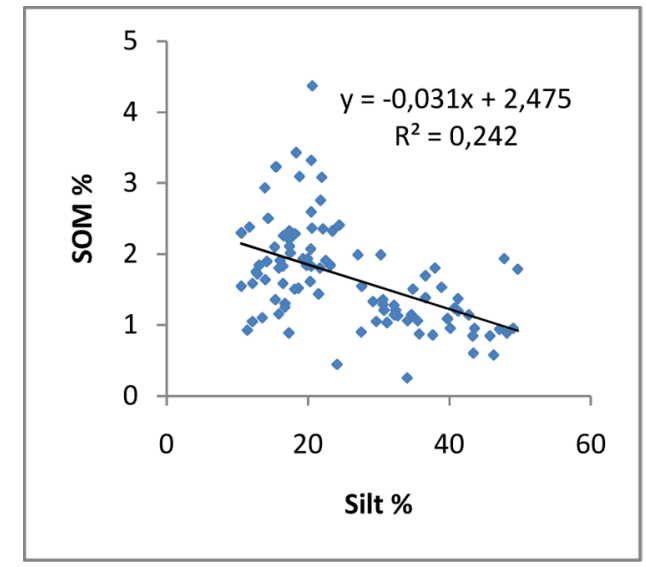

Figure 3. Correlation between SOM and Silt contents (\%) 


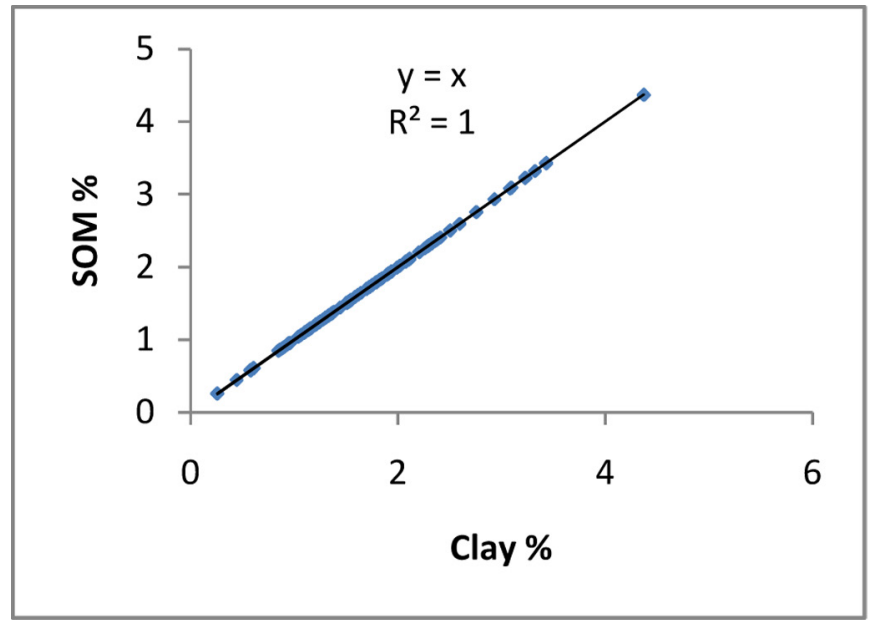

Figure 4. Correlation between SOM and Clay contents (\%)

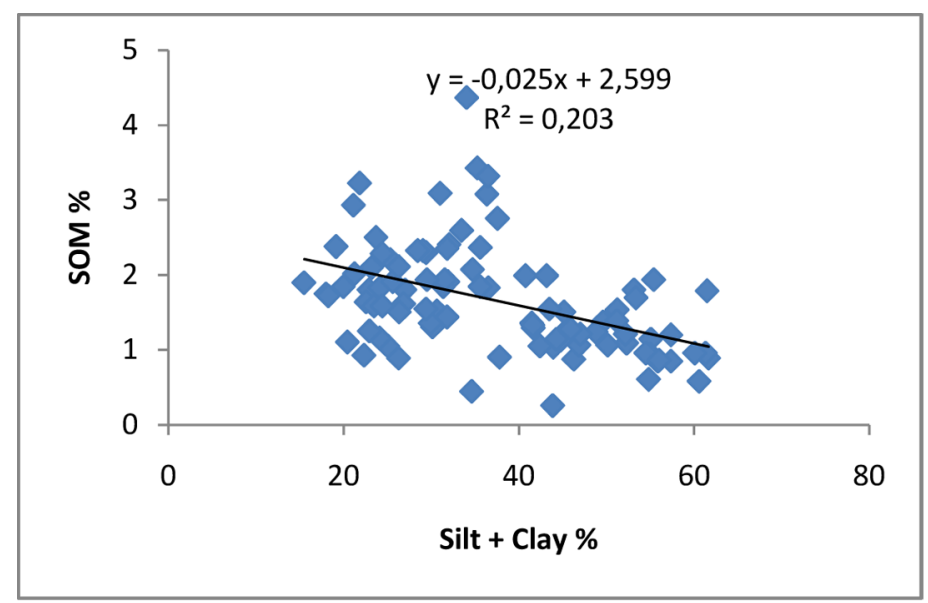

Figure 5. Correlation between SOM and Silt + Clay contents (\%) 


\section{Discussion}

\subsection{Clay, Sand and Silt proportions (\%)}

In present study no variation was observed in clay content. Soils of cold desert high altitude have originated from weathered rocks, they are immature and with large proportion of sand gravel and stone in them (Dwivedi et al., 2005). In present study, sand fraction found increasing along the altitude, whereas silt fraction was in reverse order indicating the dominance of sand forming minerals in parent materials. Hence, our findings indicated that the cold arid soils are dominated by sand alike the hot arid soils, and this relative high proportions of sand in these soil fragments causing sandy loam textural class in this region. Climate and parent material profoundly influence soil characteristics (Schinner, 1982; Yang et al., 2008). Hence, the soils of studied region have more proportion of coarse grained soil particles, which indicates the slow process of soil formation. This may be due to the climatic conditions (low temperature, higher snowfall, availability and movement of water along the altitude).

Higher silt but lower sand proportion observed at lower altitude in our study that indicates the presence of quartz, feldspars, hornblende, and micas in the soil (Ley et al., 2000). It is also assumed that the lack of smaller size particles shows the slow process of weathering in this region (Brady and Weil, 1999). Therefore, slow process of soil formation along the altitude results in very low content of clay particles which may cause low content of available mineral nutrients in this soil (Brady and Weil, 1999).

\subsection{BD, SOM and Calcium carbonate}

In the present study, BD did not vary with the altitude that indicates similar nature of soil at all the altitude. It was reported that the bulk density depends on soil structure and texture, organic matter, freezing and thawing process (Unger, 1991; Chen et al., 1998). Therefore, these factors have no significant effect on soil to change their textural class, so bulk density did not change along the different altitude. We also observed sandy loam soil at all altitude in this study. The SOM content (\%) was increasing with altitude in this investigation. Atmospheric temperature is the main climatic variable which control SOC at cold desert. Higher precipitation in the form of snow at high altitude than lower altitude and subzero temperature causes hyper aridity of soil at cold desert high altitude and suppression of microbial and enzymatic activities which results least soil organic matter decomposition that make higher accumulation of SOC (Schinner, 1982; Jacot et al., 2000; Bhattacharyya et al., 2008). Hence, this might be the reason that cold arid bioclimate of Ladakh contains more SOC and SOM. Our present findings has got support of Trumbore et al. (1996), Garten et al. (1999) and Bolstad and Vose (2001), who also reported increasing soil carbon concentration with altitude in mountainous terrain. Hence, increasing trends of SOM content (\%) with increasing altitude may be due to the constant carbon inputs and decrease rate of carbon loss at different altitude. Soil texture is another important regulator of soil organic matter decomposition and soil respiration that depends on relative proportion of clay, silt, and sand (Jenny, 1980; Schimel et al., 1985). This hypothesis is also further supported by this study, as in present studied areas comes under sandy loam textural class based on sand and silt fraction of soil. Cold desert vegetations have higher root: shoot ratios, shallower root distributions and above ground litter fall and root mortality are the two primary processes that contribute to soil carbon inputs along the elevation gradient (Yang et al., 2009; Charan et al., 2012).

This study indicated uniform high $\mathrm{CaCO}_{3}$ content (\%) at lower altitude (10000-12000 ft amsl) as compared to higher altitude $(<12000 \mathrm{ft}$ amsl). This might be due to low temperature and respiration rate and high snow precipitation at that altitude and type of the parent materials (calcite mineral in soil profiles) available there. Since, temperature affects $\mathrm{CaCO}_{3}$ equilibrium directly through its influence 
on the solubility constant and indirectly through its effect on the partition of precipitation inputs between evapotranspiration and leaching (Feng et al., 2002). Also decrease of water content or partial pressure of $\mathrm{CO}_{2}$ or increase of $\mathrm{Ca}^{2+}$ or $\mathrm{HCO}_{3}^{-}$concentrations can lead to a favorable environment for the precipitation of pedogenic form of inorganic carbon (Nordt et al., 2000). Pedogenic form of inorganic carbon accumulation in arid and semiarid soils occurs because of water deficit (evapotranspiration>prec ipitation) constraint significant leaching that helps pedogenic inorganic carbon accumulation (Nordt et al., 2000). Therefore, at lower altitudes of Ladakh has comparatively higher evaporation rate of soil and high soil mineralization, which may result in higher accumulation of $\mathrm{CaCO}_{3}$ as compared to higher altitudes.

\section{3. $p H, E C(\mu s / c m)$ and TDS (ppm)}

We did not find any significant differences in EC. These findings indicate that no major difference in cumulative salt accumulation along the altitude. However, decreasing trend of $\mathrm{pH}$ and TDS from lower altitude (10000-11000 ft amsl) to higher altitude shows that at lower altitude sites have more cumulative salt accumulation rather than higher altitude sites. This may be due to the higher accumulation of base forming cations like $\mathrm{Ca}^{+2}, \mathrm{Mg}^{+2}$, $\mathrm{K}^{+}$and higher accumulation of $\mathrm{CaCO}_{3}$ (Northcott et al., 2009). We also observed $<6.0 \% \mathrm{CaCO}_{3}$ at $<12000$ $\mathrm{ft}$ amsl, this finding confirms that this cold desert high altitude soil is calcareous in nature. Hence, our study indicated that cold desert soils are typically alkaline with broad ranges of salinity reflecting surface exposure age and local hydrological conditions (Northcott et al., 2009). Since, calcareous soils occur naturally in arid and semi-arid regions because of relatively little leaching (Brady and Weil, 1999). Therefore, it is presumed that calcareous soils of this cold desert high altitude may have developed by predominantly available calcareous parent material (calcite mineral) throughout the soil profiles.

\section{Conclusion}

These results revealed that the agriculture soil at cold desert high altitude region comes under sandy loam class, and calcareous and alkaline in nature. Hence, this soil may be suitable for growing of vegetables and legumes crops. This study also indicated the altitudinal variations in certain physico-chemical characteristics of agricultural soil at cold desert high altitude. Therefore, this study would bring attention of soil science researcher and agronomist for new soil management approaches and cultivation practices along the altitude gradients of this cold desert high altitude region.

\section{Acknowledgements}

Authors are indebted to Defence Research and Development Organization (DRDO), New Delhi, India for providing financial support to carry out this work and also highly grateful to Mr. Stanzin Tsetar and the farmers of this region for their kind assistance during soil sample collection.

\section{References}

Bashour, I. I., Sayegh, A. H. 2007. Methods of analysis for soils of arid and semi-arid regions. FAO Viale delle Terme di Caracalla, 00153 Rome, Italy.

Bhattacharyya, T., Pal, D. K., Chandran, P., Ray, S. K., Mandal, C., Telpande, B. 2008. Soil carbon storage capacity as a tool to prioritize areas for carbon sequestration. Current Science. 95, 482492.

Bolstad, P.V., Vose, J. M. 2001. The effects of terrain position and elevation on soil $\mathrm{C}$ in the southern Appalachians. In: (eds Lal, R., Kimble, J. M., Follett, R. F., Stewart, B. A.). pp. 45-51. 
Bowman, W. D., Cairns, D. M., Baron, J. S., Seastedt, T. R. 2002. Islands in the sky: Alpine and treeline ecosystems of the Rockies. Baron, J.S., ed. Rocky Mountain Futures: An Ecological Perspective. Washington (DC): Island Press. pp. 183-202.

Brady, N. C., Weil, R. R. 1999. Nature and properties of soil, 12th Ed. Prentice-Hall, Inc. Pearson Education, Upper Saddle River, NJ, USA.

Campbell, I.B., Claridge, G.G.C. 1987. Antarctica. Soils, weathering processes and environment. Elsevier, Amsterdam, New York, 368.

Charan, G., Bharti, V.K., Jadhav, S.E., Kumar, S., Angchok, D., Acharya, S., Kumar, P., Srivastava, R.B. 2012. Altitudinal variations in carbon storage and distribution patterns in cold desert high altitude region of India. African Journal of Agricultural Research. 7, 6313-6319.

Chen, Y., Tessier, S., Rouffignat, J. 1998. Soil bulk density estimation for soil tillage system and soil texture. Transactions of the ASAE. 41, 1601-1610.

Dwivedi, S.K., Sharma, V.K., Bharadwaj, V. 2005. Status of available nutrients in soil of cold arid region of Ladakh. Journal of the Indian Society of Soil Science. 53, 421-423.

Feng, Q., Endo, K.N., Cheng, G. 2002. Soil carbon in desertified land in relation to site characteristics. Geoderma. 106, 21-43.

Garten, C. T., Post, W. M., Hanson. P. J., Cooper, L. W. 1999. Forest soil carbon inventories and dynamics along an elevation gradient in the southern Appalachian Mountains. Biogeochemistry. 45, 115-145.

Jacot, K.A., Luscher, A., Nosberger, J., Hartwig, U. A. 2000. Symbiotic N2 fixation of various legume species along an altitudinal gradient in the Swiss Alps. Soil Biology And Biochemistry. 32, 10431052.
Jenny, H. 1980. The Soil Resource: Origin and Behavior. Springer-Verlag, New York, NY, USA.

Jobbagy, E.G., Jackson, R.B. 2000. The vertical distribution of soil organic and its relation to climate and vegetation. Ecology Application. 10, 423-426.

Ladakh Autonomous Hill Development Council (LAHDC). 2005. http://leh.nic.in/ahdc.htm. Accessed: July 2005.

Ley, R.E., Lipson, D.A., Schmidt, S.K. 2000. Microbial biomass levels in barren and vegetated high altitude Talus soils. Soil Science Society of America Journal. 65, 111-117.

Li, W.H., Zhou, X.M. 1998. Ecosystems of QinghaiXizang (Tibetan) plateau and their influence on environments. Guangdong Science And Technology Press, Guangzhou.

Mandal, C., Mandal, D. K., Srinivas, C.V., Sehgal, J., Velayutham, M. 1999. Soil climatic database for crop planning in India. Technical Bulletin No. 53. NBSS and LUP. Pp. 1014.

Mani, M.S. 1990. Fundamentals of high altitude biology. 2nd Ed. Oxford and IBM Publishing Co. Pvt. Ltd., New Delhi.

Nordt, L.C., Wilding, L.P., Drees, L.R. 2000. Pedogenic carbonate transformations in leaching soil system: implications for the global $\mathrm{C}$ cycle. In: Global Climate Change and Pedogen ic Carbonates (eds Lal, R., Kimble, J.M., Eswaran, H., Stewart, B.A.), CRC Press, Boca Raton, USA. Pp. 43-64.

Northcott, M.L., Gooseff, M.N., Barrett, J.E., Zeglin, L.H., Takacs-Vesbach, C.D., Humphrey, J. 2009. Hydrologic characteristics of lake and stream-side riparian margins in the McMurdo Dry Valleys, Antarctica, Hydrol. Process. 23, 1255-1267. 
Oechel, W. C., Vourlitis, G. L., Hastings, S. J., Zulueta, R.C., Hinzman, L., Kane, D. 2000. Acclimation of ecosystem $\mathrm{CO}_{2}$ exchange in the Alaskan Arctic in response to decadal climate warming. Nature. 406, 978-981.

Schimel, D., Stillwelml, M.A., Woodmansee, R.G. 1985. Biogeochemistry of C, N, and P in a soil. Assessment Methods for Soil Carbon. Lewis Publishers, Boca Raton, FL.

Schinner, F. 1982. Soil microbial activities and litter decomposition related to altitude. Plant Soil .65, 87-94

Sharma, V. K., Dwivedi, K. S., Tripathi. D., Ahmed, Z. 2006. Status of available major and micronutrients in the soils of different blocks of Leh district of cold arid region of Ladakh in relation to soil characteristics. Journal of the Indian Society of Soil Science. 54, 248-250.

SPSS. 1996. Statistical Packages for Social Sciences, Version 11.5. SPSS Inc., Chicago, IL, USA.

Tandon, H.L.S. 1993. Methods of analysis of soil, plants, water and fertilizers. Publ. FDCO. Pp. 144.

Trumbore, S.E., Chadwick, O.A., Amundson, R. 1996. Rapid exchange between soil carbon and atmospheric carbon dioxide driven by temperature change. Science. 272, 393-396.
Unger, P.W. 1991. Overwinter changes in physical properties of no tillage soil. Soil Science Society of America Journal. 55, 778-782.

Walker, D.A., Molenaar, J.G., Billings, W.D. 2000. Snow-vegetation interactions in tundra environments. In: Snow Ecology (ed. by Jones, H. G., Pomeroy, J., Walker, D. A., Wharton, R.), Cambridge University Press, Cambridge, UK. Pp. 264-322.

Walkley, A., Black, C.A. 1934. An examination of different methods for determining soil organic matter and proposed modifications of the chromic acid titration method. Soil Science. 37, 29-38.

Yang, Y.H., Fang, J.Y., Ji, C.J., Han, W.X. 2009. Above-and belowground biomass allocation in Tibetan grasslands. Journal of Vegetable Science. 20, 177-184.

Yang, Y., Fang, J., Tang, Y., Ji, C., Zheng, C., Hi, J., Zhu, B. 2008. Storage, patterns and control of soil organic carbon in Tibetan grasslands. Global Change Biology. 14, 1592-1599. 